\title{
Foraminiferal StUdy of NKPoro Shale Exposures, Calabar Flank (SE NigERIA): AGE AND DEPOSITIONAL ENVIRONMENT
}

\section{AsuKWo EsSIEN ITAM ${ }^{1}$, Victoria INYANG EMEKA ${ }^{2}$ AND CHIMEZIE NDUNAGUM EMEKA ${ }^{1 *}$}

1 University of Calabar, Calabar, Department of Geology, Calabar, Cross River State, Nigeria

2 University of Calabar, Faculty of Oceanography, Calabar, Cross River State, Nigeria

* Corresponding Author, m-neck@live.com

Received on 11 October 2019

Received in revised form on 21 October 2019

Accepted on 24 October 2019

Editor: Maria Virginia Alves Martins, Universidade do Estado do Rio de Janeiro, Brazil

\section{Abstract}

Foraminiferal analysis of the sedimentary deposits of Nkporo shale exposed at PAMOL along Calabar/Odukpani Road, in the Calabar Flank, Southeastern Nigeria, was investigated in order to determine its geological age and paleoenvironmental conditions. The lithology is predominantly composed by shale with traces of siltstone and sandstone. Shale is generally light to dark grey, occasionally light brown, sub-fissile to fissile, moderately hard, carbonaceous, and slightly ferruginous. Results of foraminiferal analysis showed that the samples consist predominantly of arenaceous/agglutinated benthic foraminifera. Calcareous planktic foraminifera are absence and calcareous benthic taxa are almost absence of calcareous. The occurrence of the following foraminifera taxa Ammobaculite sp., Haplophragmoides sabariense, Haplophragmoides talokaense, Trochammina sp., Trochammina

\section{Introduction}

The Calabar Flank has been extensively studied from a geological perspective (e.g. Reyment, 1965; Murat, 1972; Adeleye and Fayose, 1978; Petters, 1979, 1980; Petters and Ekweozor, 1982; Akpan, 1985; Nyong and Ramanathan, 1985; Braide, 1987; Edet and Nyong, 1993, 1994; Adegbie and Bassey, 2007; Ekpo et al., 2012, 2013; Boboye and Okon 2014; Ukpong and Ekhalialu, 2018; Itam et al., 2019). Early Investigations of its biostratigraphy have been documented by Reyment (1965), Dessauvagie (1965) and Nyong and Ramanathan (1985). Braide (1987) examined the clay mineralogy of Tertiary subsurface sediments of the Calabar Flank. Edet and Nyong (1993) studied the Campanian-
Citation:

Itam, A.E., Emeka, V.I., Emeka C.N., 2019. Foraminiferal study of Nkporo shale exposures, Calabar Flank (SE Nigeria): age and depositional environment. Journal of Sedimentary Environments, 4 (4): 369-378.

dustuna, Ammobaculites amabensis and Bolivina sp. suggest that sediments in the study area were deposited during the Maastrichtian age. The paleo-depositional-environment should occur in transitional marine settings, probably a marsh/lagoon. In the study area, calm hydrodynamic conditions prevailed. They favored the accumulation of finegrained sediment and organic matter which gave rise to oxygen scarcity. The environment would be stressful for benthic foraminifera not only because of oxygen scarcity but also due to the variability of water salinity (hypo to hypersaline).

Keywords: Biostratigraphy. Foraminiferal analysis. Agglutinated benthic. Maastrichtian. Cretaceous. Transitional and Marine Setting.

Maastrichtian depositional environments and sea-level history on the Calabar Flank using palynofacies. Ekpo et al. (2012) analyses the Cretaceous sediments of the Calabar Flank based on geochemistry and organic petrography. The petroleum potentials of Cretaceous outcrops from the Calabar Flank has been evaluated by Ekpo et al. (2013). A sedimentological and geochemical study of Cretaceous strata of the Calabar Flank has been documented by Boboye and Okon (2014). Ukpong and Ekhalialu (2018) studied the Cenomanian-Turonian foraminifera and palynomorphs of the Calabar Flank based on age and depositional environment. Detailed palynological evaluation of 


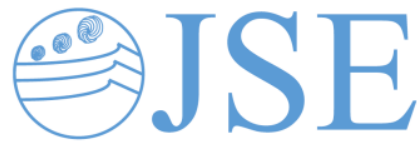

RESEARCH PAPER

Cretaceous sediments of the Calabar Flank has been assessed by Itam et al. (2019).

Calabar Flank was first described by Murat (1972) as a depositional basin within the southeastern part of Nigeria (Nyong and Ramanathan, 1985) including Cretaceous and Tertiary sediments (Itam et al., 2016, 2017). The Nkporo Shale corresponds to Late Cretaceous sediment of this basin. Its upper part has been dated as Maastrichtian based on foraminiferal species including Heterobelix reussi (Cushman, 1938), Contusotruncana fornicata (Plummer, 1931), as Globotruncana fornicata Plummer, 1931, and Rugoglobigerina sp. while its lower part was described as Late Campanian with regards to the occurrence of Afrobolivina afra Reyment, 1959, as Bolivina afra (Reyment, 1959), as well as Gabonita elongata (de Klasz and Meijer, 1960), Gabonella lata de Klasz and Meijer, 1960 (as Gabonita lata) and Praebulimina bantu de Klasz, Magné and Rérat, 1963 (Kumaran and Ramanathan, 1986).

Information on the biostratigraphy and paleoenvironment of the Nkporo Shale (also called PAMOL Shale in this article) is sparse in literature. It outcrops at PAMOL palm oil plantation, along Calabar/Odukpani road in the Calabar Flank. Apart from studies carried out on the Palynostratigraphy of the Nkporo Shale exposures (Late Campanian-Maastrichtian) and Palynostratigraphy of PAMOL shale deposit by Edet and Nyong (1994) and Itam et al. (2017) on some selected outcrops, no other biostratigraphic work has been documented on this formation.

Consequently, this work intends to contribute to the study of the biostratigraphy of the Upper Cretaceous sediments in Calabar Flank (Fig. 1) aiming to: 1) ascertain the age of PAMOL shale and; 2) interpret the paleoenvironment and paleoecological settings of the study area.

\section{Geological Setting}

Calabar Flank is an epeirogenic depositional basin, which is bounded to the north by the Oban Massif, to the south by the Niger Delta basin, to the east by the Cameroon volcanic ridge and to the west by the Ikpe platform (Figs. 2 and 3). The origin of the Calabar Flank is closely linked with the separation of the African plate from the South American plate (Figure 3A and the formation of the Gulf of Guinea during the Mesozoic era (Petters, 1982; Adegbie and Bassey, 2007). The geologic history of the sedimentary basins of Southern Nigeria are marked by three tectonic phases (Murat,1972). During tectonic activity, the axis of the main basins was displaced resulting in the formation of three successive basins, one of which is present in Calabar Flank (Adegbie and Bassey, 2007). Predominant tectonic structures of the Calabar Flank (Figure 3B and C) comprise a NW-SW trending horst structure (Ituk High) and a graben, the Ikang
Trough (Nyong and Ramanathan, 1985; Petters and Reijers, 1987). These structures, in addition to fluctuations of global sea level, controlled basin sedimentation and distribution of sedimentary facies (Murat, 1972; Nyong and Ramanathan, 1985; Nyong, 1995).

Sedimentary successions in the Calabar Flank are presented in Figure 4. The thickness of the encountered sedimentary sequense is over $3500 \mathrm{~m}$ and onlaps along the peripheries of the Oban Massif basement complex (Nyong, 1995). This formation has a good exposure along CalabarIkom Road with five Cretaceous subdivisions and a Tertiary lithostratigraphic unit. The oldest basal unit is the Awi Formation which is settled non-conformably on the Precambrian Oban Massif basement complex. Awi Formation is characterized by fluvio-deltaic shale and arkosic cross-stratified sandstone and has been assigned an Aptian age (Adeleye and Fayose, 1978). The Mfamosing Limestone, which overlies the Awi Formation is considered to be Middle - Upper Albian age (Petters, 1982), indicating the earliest marine transgression within the basin. Overlying this Formation is the Late Albian-Cenomanian through Turonian Ekenkpon Shale (Petters and Reijers, 1987; Ukpong and Ekhalialu, 2015; Una et al., 2017). This extensive shale deposit is characterized by minor intercalations of mudstone and marl which occurred as a result of the subsiding faulted blocks that initiated horst and graben structures in the basin. The Ekenkpon Formation is overlain by the New Netim Marl of Coniacian age (Nyong, 1995). A major unconformity within the basin and other related Cretaceous basins in Nigeria marked the Santonian period. Conversely, the Nkporo Shale, which has a Late Campanian-Early Maastrichtian age (Edet and Nyong, 1994; Itam et al., 2017) capped the Mesozoic sedimentation as well as the marine transgression within the Calabar Flank. Tertiary continental deposits which consist of coarse to medium grained sands of the Benin Formation (Itam et al., 2016) completes the sedimentation episode in the basin.

\section{Materials and Methods}

This work was undertaken using outcrop exposures from three locations (L1-3) at PAMOL Rubber Plantation Estate, along Calabar/Odukpani Road (Fig. 1, in Cross River State, Southeastern Nigeria. The coordinates for the studied locations are: Location 1 (L1), N 5 5'55.65" and E 8'20'38.12"; Location 2 (L2), N 56'24.72" and E $8^{\circ} 20^{\prime} 30.31^{\prime \prime} ;$ and Location 3 (L3), N 56'44.09' " and E 8०20'31.11"'.

Shale outcrop samples were collected from the mentioned three (3) different locations (L1-3) at PAMOL Rubber Plantation Estate, along Calabar/Odukpani Road in Cross River State, Southeastern Nigeria. The sampling area was very weathered but adequate care was taken to trench and obtain unweathered samples for use in this study. The 
retrieved samples were stored in well labeled sample bags and analyzed in a laboratory.

The conventional approach for processing samples for foraminiferal biostratigraphy was employed. The samples were air-dried and disintegrated, following which $20 \mathrm{~g}$ of each dried sample was soaked overnight in water with a teaspoonful of anhydrous sodium. The disaggregated samples were carefully washed over a $63 \mu \mathrm{m}$ mesh sieve using clean tap water. The $>63 \mu \mathrm{m}$ sediment fraction was dried with a hotplate at a low temperature of $40^{\circ} \mathrm{C}$ and then sieved into coarse, medium and fine sand fractions respectively. The dried residues were stored into well labeled sample bag. Picking was done with the aid of a picking tray and a stable hair paint brush $\left(\mathrm{N}^{\circ}\right.$. 0) under binocular microscope. Identification of the foraminiferal taxa was based on Loeblich and Tappan $(1964,1987)$ and relevant websites such as marinespecies.org.

\section{Results and Discussion}

\subsection{Foraminiferal biostratigraphy}

Three locations L1, L2 and L3 were sampled for foraminifera in the study area. L1 was completely devoid of foraminifera. L2 showed highest occurrence of benthic foraminifera with highest diversity. L3 was characterized by a single calcareous benthic foraminifera taxon.

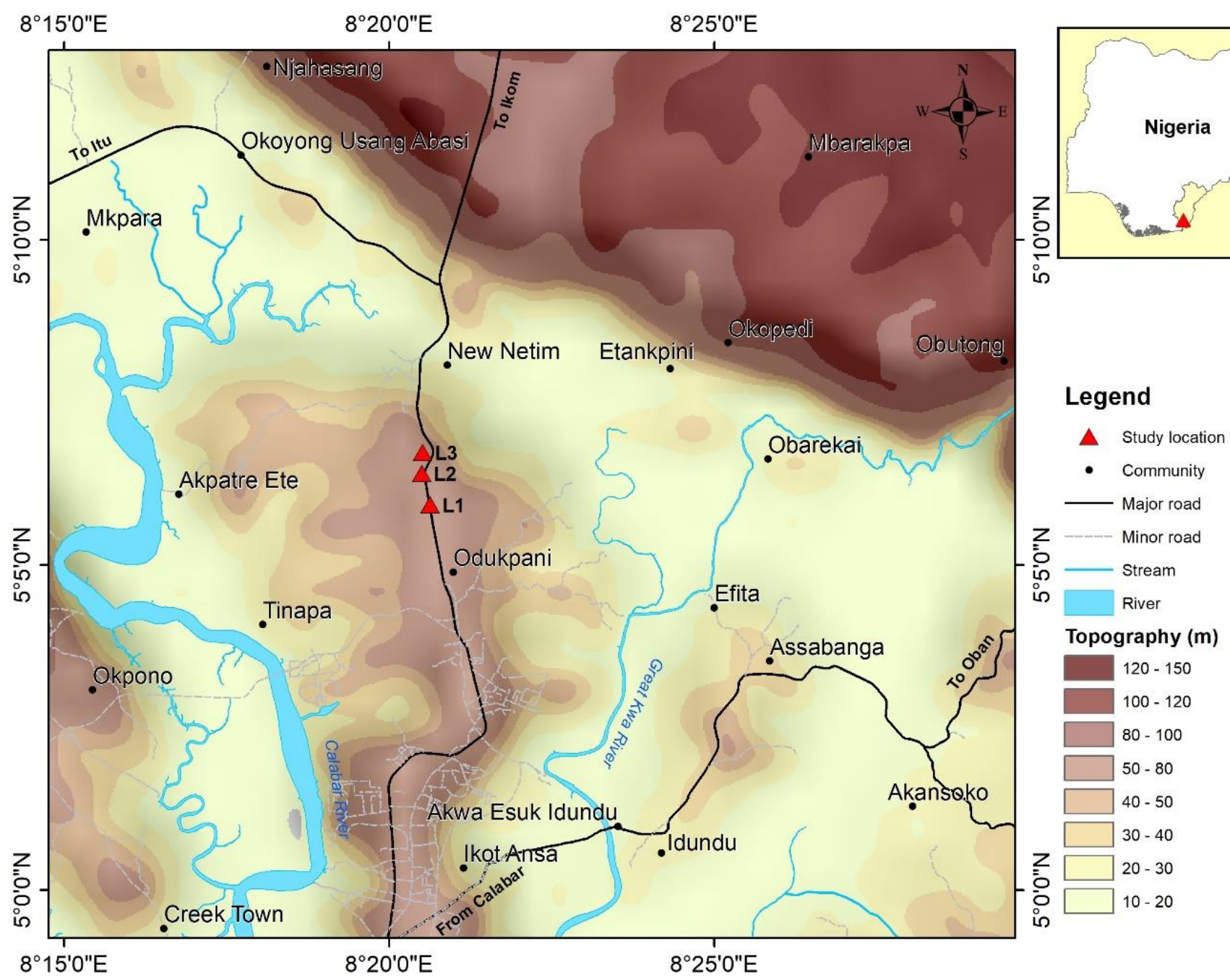

Fig. 1. Shaded relief map showing topography of the study area (adapted from Google Earth, 2019).

Biostratigraphic results of the PAMOL shale samples (in L2) revealed the occurrence of relatively high abundance but low diversity of foraminiferal assemblages. Ten (10) foraminiferal taxa comprising almost entirely agglutinated benthic foraminifera were recovered from the studied area
(Table 1). Planktonic foraminiferal species where not found in the samples. The recovered foraminifera specimens were rather degraded. This may have been due to high organic matter decomposition and the contact of carbonates with continental freshwater in general with relatively low $\mathrm{pH}$. A 
total of 212 foraminifera specimens represented by nine (9) different benthic agglutinated species and one (1) benthic calcareous species were recovered from the samples of the investigated area (Table 1). Agglutinated species including Haplophragmoides sahariense, Haplophragmoides talokaense, Haplophragmoides sp, Ammobaculites amabensis, Ammobaculites coprolithiformis, Ammoidiscus kiowensis, Trochammina dutsuna, Trochammina sp. and Ammobaculites sp. and calcareous species including Bolvina sp, were recovered from the shale samples.

Location 2 (L2) had the highest abundance and diversity of foraminifera. A single species was recorded in location 3
(L3) and a total absence of foraminiferal taxa was observed in location 1(L1).

The investigated area of the PAMOL shale have been dated as Maastrichtian (Upper Cretaceous). This age was established based on the occurrence of stratigraphic markers such as Ammobaculites sp., Haplophragmoides sabariense, Haplophragmoides talokaense, Trochammina sp, Trochammina dustuna, Ammobaculites amabensis and Bolivina (Petters, 1979; Fadiya and Adebambo, 2016). This agrees with the findings of Kumaran and Ramanathan (1986), placing the exposure at the upper part of the formation.

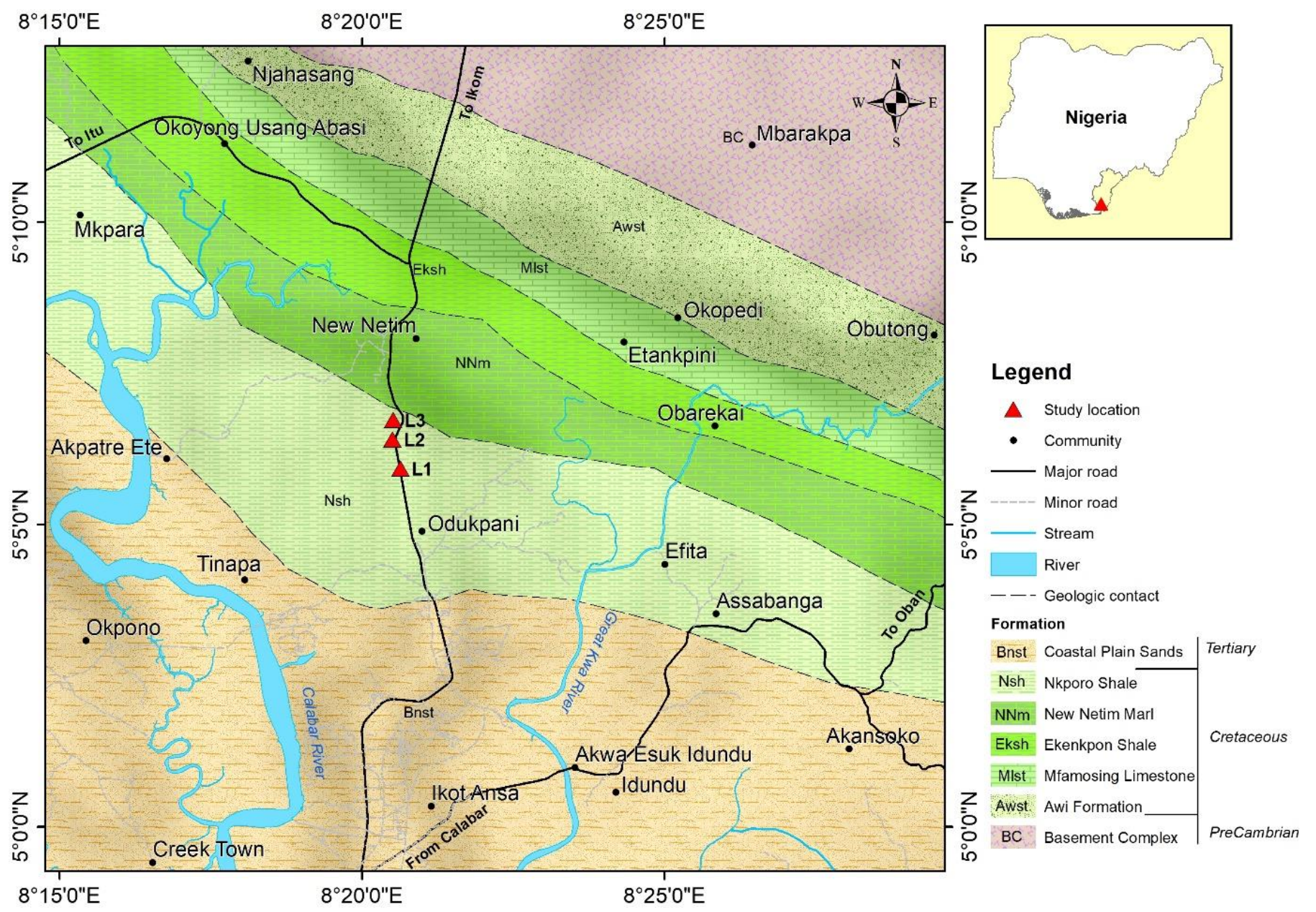

Fig. 2. Geological map of the Calabar Flank, showing the study locations (adapted from Google Earth, 2019).

\subsection{Paleoenvironmental analysis}

The paleoenvironmental conditions at the time of sediment deposition was interpreted based on recovered foraminifera. Foraminifera are known to occur in tidally influenced shallow water environments and in marine settings ranging from marginal to deep seafloor (SchröderAdams, 2006; Ukpong et al., 2015). The ancient environments where these taxa lived can be inferred using various methods, one of which is based on the shell-type (morpho-group) ratio ternary plot (Armstrong and Brasier, 2005). Here, the percentage of the three-shell types (porcelaneous, hyaline and agglutinated) of foraminifera in a particular sample is used to distinguish specific environment in the marine setting. The ternary plot of PAMOL shale reveals the total dominance of the agglutinated shell type (Fig. 5). A comparison of the assemblage composition with modern microfauna, studied by Murray $(1973,1991)$ and Fadiya and Adebambo (2016) indicates the occurrence of a shallow marine depositional environment in the study area. 

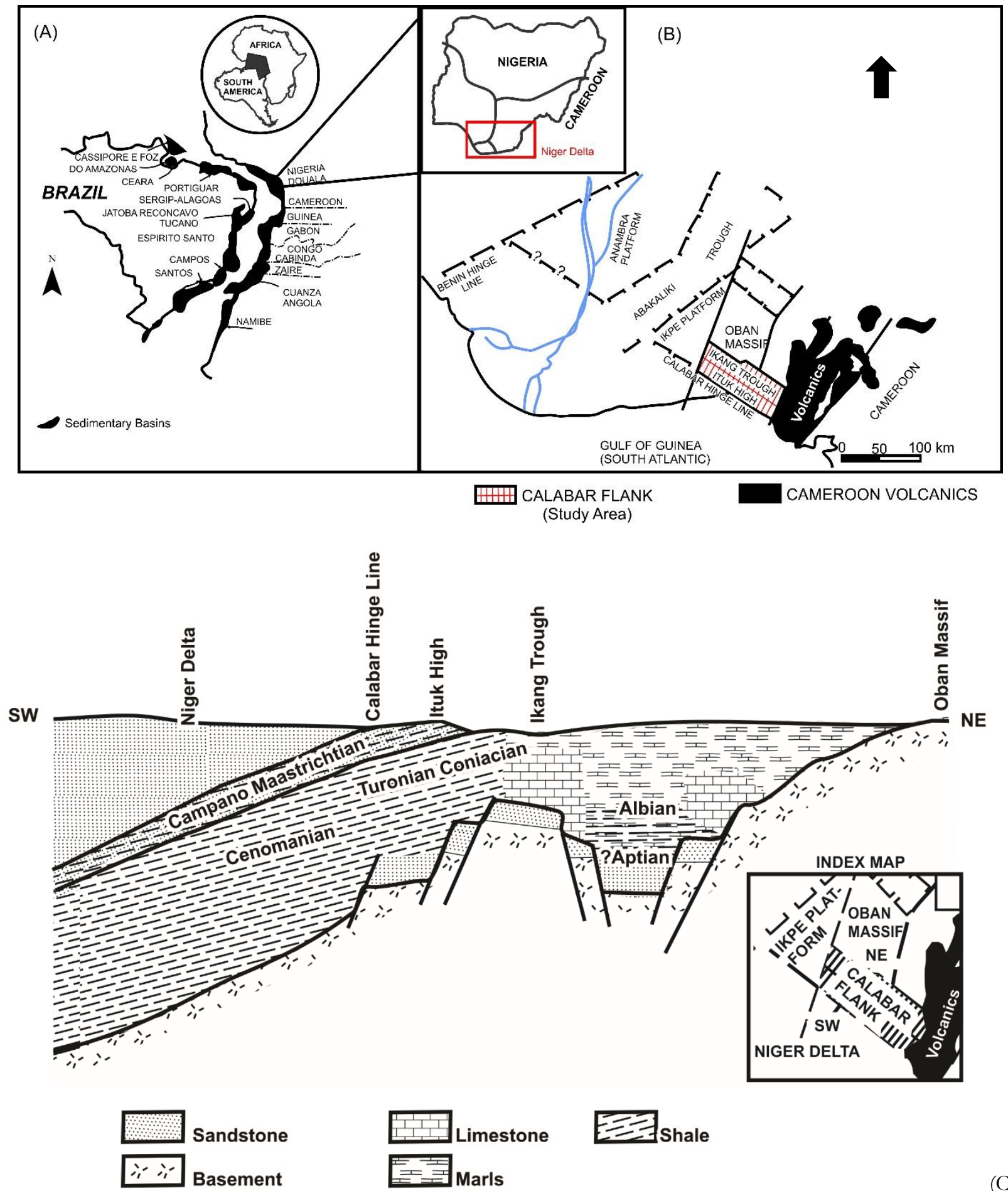

Fig. 3. (A) Tectonic origin, (B) structural map and (B) stratigraphic cross-section of the Calabar Flank and adjoining areas (after: Murat, 1973; Nyong and Ramanathan, 1985) 
Journal of Sedimentary Environments

Published by Universidade do Estado do Rio de Janeiro

4 (4): 369-378. October-December, 2019

doi: $10.12957 /$ jse.2019.46129

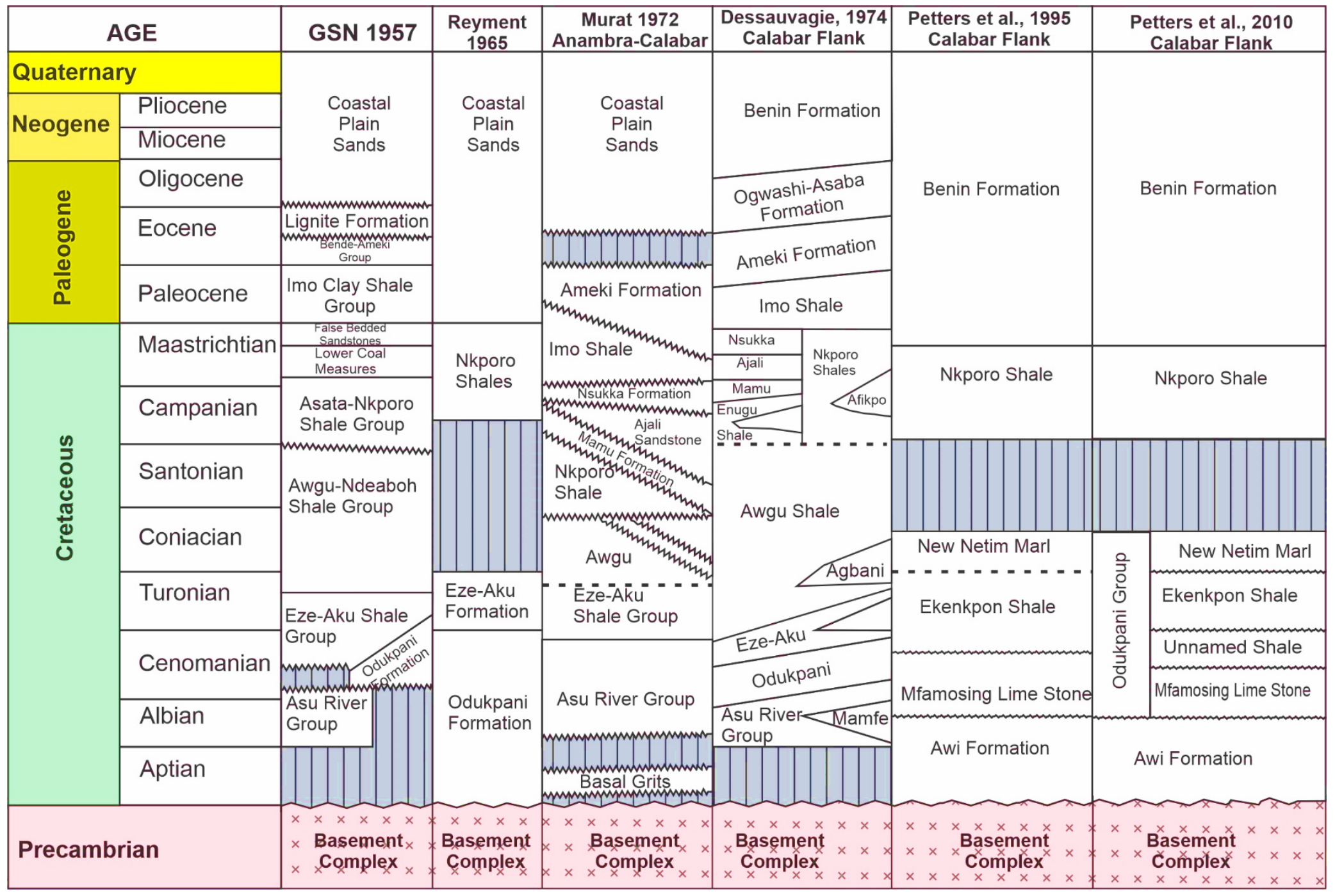

Fig. 4. Lithostratigraphic correlation between Calabar Flank, Abakaliki Trough, Anambra Basin and the Middle Benue Trough (modified after Petters et al., 1995; Petters et al., 2010). 
Tab. 1. Foraminifera recovered from the study area.

\begin{tabular}{|c|c|c|c|c|}
\hline $\begin{array}{l}\text { Sample } \\
\text { location }\end{array}$ & Foraminiferal species & $\begin{array}{l}\text { Foraminiferal test } \\
\text { type }\end{array}$ & $\begin{array}{l}\text { Foraminiferal } \\
\text { type }\end{array}$ & $\begin{array}{l}\text { Number of } \\
\text { specimens }\end{array}$ \\
\hline $\mathbf{L} 1$ & Barren & Nil & Nil & Nil \\
\hline \multirow[t]{9}{*}{$\mathbf{L} 2$} & Haplophragmoides sabariense Petters, 1979 & Agglutinated & Benthic & 83 \\
\hline & Haplophragmoides talokaense Petters, 1979 & Agglutinated & Benthic & 18 \\
\hline & Haplophragmoides sp. & Agglutinated & Benthic & 38 \\
\hline & Ammobaculites amabensis Petters, 1979 & Agglutinated & Benthic & 14 \\
\hline & Ammobaculites coprolithiformis (Schwager, 1867) & Agglutinated & Benthic & 08 \\
\hline & Ammodiscus kiowensis Loeblich and Tappan, 1950* & Agglutinated & Benthic & 01 \\
\hline & Trochammina dutsuna Petters, 1979 & Agglutinated & Benthic & 21 \\
\hline & Trochammina sp. & Agglutinated & Benthic & 01 \\
\hline & Bolvina sp. & Hyaline & Benthic & 03 \\
\hline L3 & Ammobaculites sp. & Agglutinated & Benthic & 25 \\
\hline
\end{tabular}

*Basis of record: Ellis, B. F.; Messina, A. (1940-2015). Catalogue of Foraminifera. Micropaleontology Press, American Museum of Natural History, New York. and Hayward, B.W.; Le Coze, F.; Gross, O. (2018). World Foraminifera Database. Ammodiscus kiowensis Loeblich \& Tappan, 1950. Accessed at: http://www.marinespecies.org/Foraminifera/aphia.php?p=taxdetails\&id=908134 on 2019-10-19

Relatively high abundance of Haplophragmoides, Ammobaculites and Trochamina was recorded in the study area. High percentages of this genera are indicative of brackish water conditions (Murray, 1991).

The total absence of planktonic foraminifera species is suggestive of a shallow marine/transitional marsh to lagoon environment. Whightman (1990) identified the paleoenvironment of the Cretaceous sediment of the Lusitanian Basin in Portugal as marsh and estuarine based on the high occurrence of Haplophragmoides, Ammobaculites and Trochamina. Martins et al. (2014) used statistical analysis and a multiproxy approach to identify biotopes and their distribution control in Ria de Aveiro channels (Portugal). These authors found, in the hyposaline lagoonal area, near the rivers outflow, foraminiferal assemblages composed by high abundance of euryhaline agglutinated species very tolerant to variations of salinity. This marsh/ near march biotope was characterized by fine-grained substrates with very high content of organic matter. Alves Martins et al. (2019) also observed the same pattern of distribution with bolivinids dominating areas associated to high contents in organic matter under lagoonal higher marine water influence or to neritic marine settings (Martins et al., 2017). Laut et al. (2016 a, b) observed that in estuarine environments calcareous foraminifera species were associated with high salinity, temperature and $\mathrm{pH}$ values while agglutinated species were associated with muddy sediment, high contents in total organic matter and lower salinity. High occurrence of calcareous benthic with a distribution of over $60 \%$ of the total number of forms would imply an open marine setting (Horvath et al., 1989; Nagy and Alve, 1987) or the presence of higher marine influence in transitional settings (Martins et al. , 2014; Alves Martins et al., 2019). Murray (1991) and Sen Gupta (1999) observed that the predominance of calcareous taxa with an increased diversity is suggestive of a change from a brackish marginal marine environment to an open neritic condition. Fadiya and Adebambo (2016) suggested the paleoenvironment of the Upper Cretaceous sediment of Fika Shale in Bornu Basin, Northern Nigeria as lagoonal and estuarine based on the predominance of agglutinated benthic foraminiferal species (Ammobaculites, Haplophragmoides and Ammotium) which are characteristic of brackish water settings. Low diversity of foraminifera in the study area is typical of modern transitional environment such as lagoons and estuaries (Murray, 1991; Martins et al., 2016; Raposo et al., 2016).

\subsection{Paleobathymetry}

Paleobathymetry analysis was carried out using the highest occurrence of taxa. Planktonic foraminifera abundance and diversity increases from shallow water to deeper depths (Armstrong and Brasier, 2005). The total absence of planktonic foraminifera taxa in the samples 
indicates that the study area was within a shallow water environment. According to Haq and Boersma (1998), the shallow continental shelf is characterized by the absence of planktonic species. The presence of arenaceous/agglutinated foraminifera genera, such as Ammobaculites, Haplophragmoides, and Trochammina indicates water levels within marginal marine to shallow inner marine setting. In these shallow waters foraminifera density and diversity is in general low (Haq and Boersma, 1998; Delavy et al., 2016; Laut et al., 2016 a, b; Raposo et al., 2016).

\subsection{Paleoecological analysis}

Paleoecologic information of Cretaceous benthic species, which are particularly restricted to shallow epeiric seas, like Benue Trough and adjoining basins (Chad Basin and Calabar Flank inclusive) is lacking.

Haplophragmoides is the genus with the highest abundance in the sediments of the study area. It is an epifaunal to shallow infaunal detritivore, living in muddy to sandy
RESEARCH PAPER

sediment within cold temperate climatic settings and thrives well in marshes, hyposaline lagoons, estuaries to bathyal water depths (Bronnimann, et al., 1992; Murray, 2006). Ammobaculites spp. are infaunal deposit feeders that thrives well mostly on muddy sediment under brackish to normal marine saline conditions from marsh to open sea environments of temperate - tropical waters (Murray, 2006).

The prevalence of low energy hydrodynamics in the study area favored the accumulation of fine sediment and organic matter which led to oxygen deficiency, only allowing the presence of species tolerant to oxygen depletion, such as A. amabensis. This species is related to high organic influx and seems to tolerate anoxia in the depositional settings (Petters,1980; Koutsoukos et al, 1990; Murray, 1991). Trochammina is epifaunal or infaunal herbivore or detritivore, dwelling in intertidal-open sea zones (Murray, 2006). It can tolerate a wide range of salinities and can cope in low oxygen levels. The occurrence of Trochammina species in the investigated area should be related to fluctuations in oxygen levels and water salinity.

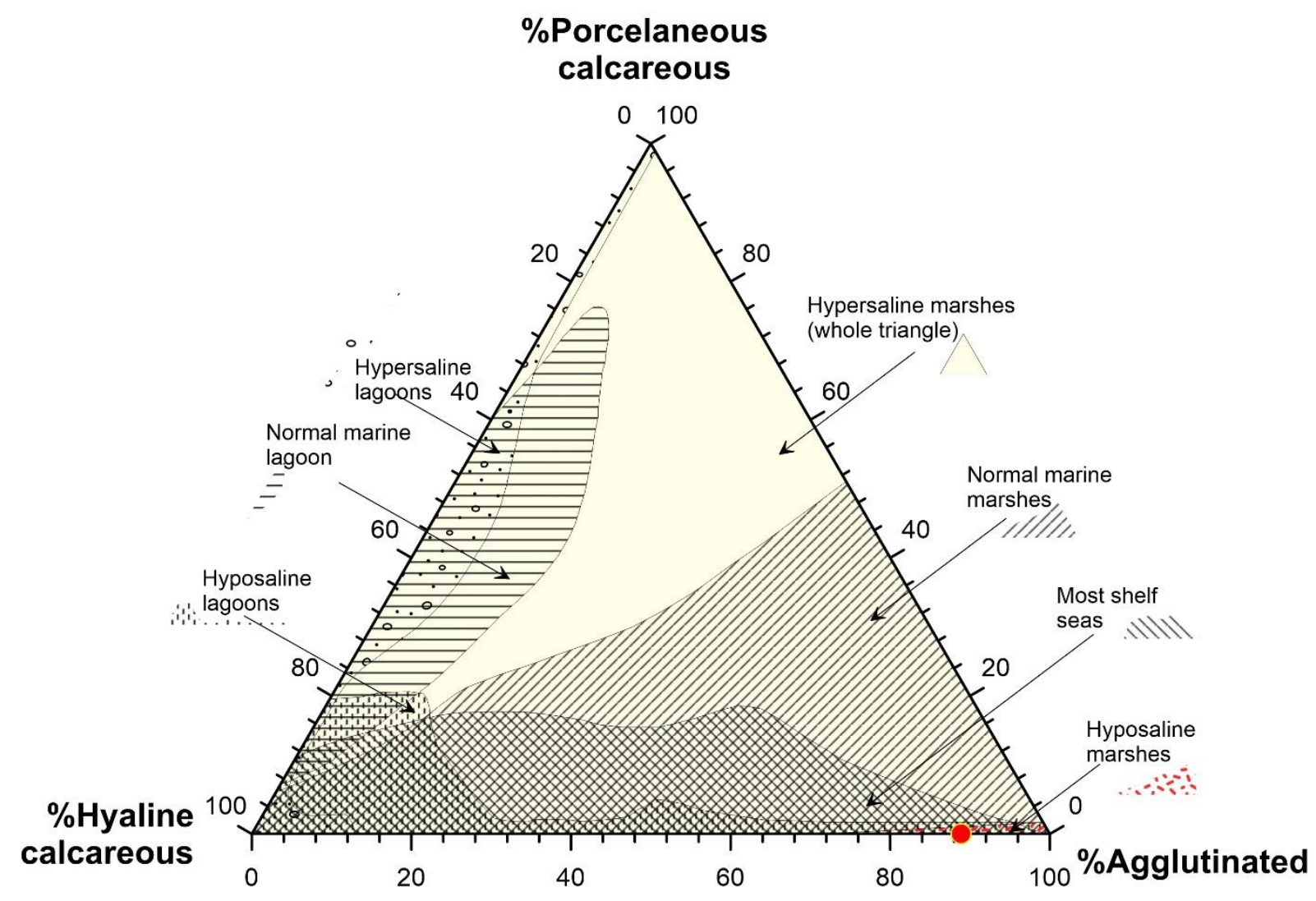

Fig. 5. Ternary plot of shell type ratio showing the paleoenvironment of PAMOL samples (after: Murray, 1973, 1991).

The near absence of calcareous benthic foraminifera in the study area is suggestive of oxygen deficiency because oxygen is essential during the chemical reaction which leads to the formation of calcium carbonate tests (Fadiya and
Adebambo, 2016). The environment would be stressful for benthic foraminifera not only due to oxygen scarcity but also due to fluctuations in water salinity from hypo to hypersaline conditions. According to the morphogroup model of this 
area, the predominance of benthic agglutinated foraminifera suggests stressful marginal marine environments, such as lagoons, marshes, estuaries and epeiric seas. The absence of planktonic species and high abundance of benthic foraminifera such as Haplophragmoides, Ammobaculites and Trochammina lets infer that the PAMOL shale was deposited in shallow marine/transitional, brackish water, marsh to lagoon environment. The abundance of agglutinated foraminifera taxa gives support to this inference (Murray, 2006).

\section{Conclusion}

The area investigated (in L2) yielded relatively high abundance and low diverse assemblages of foraminifera. Species recovered and identified in this site suggest the presence of Maastrichtian foraminiferal assemblages. This indicates that PAMOL Shale is the upper part of Nkporo Shale. The total absence of planktonic foraminifera taxa and the large dominance of agglutinated foraminifera species allow to deduce that the paleoenvironment of deposition was a shallow marine transitional setting with large salinity oscillation.

This study suggests that the area under investigation, during the Maastrichtian, was a hyposaline marginal marine environment consisting of marshes, lagoons and/or estuaries. It should be a calm environment, with high influx of detrital organic matter and oxygen deficiency.

\section{Acknowledgement}

The authors would like to acknowledge the staff of South Sea Petroleum Nigeria Limited for their assistance in the laboratory analyses of the field data. They also wish to specially thank all the reviewers of this work. Thank you for all your help.

\section{References}

Adegbie, A.T., Bassey, C.E., 2007. Cretaceous Foraminiferal Biostratigraphy and Palaeoecology of Ikono-1 Well, Calabar Flank, Southeastern Nigeria. Journal of Mining and Geology 43 (1) $31-41$

Adeleye, D.R., Fayose, E A., 1978. Stratigraphy of Type Section of Awi Formation, Odukpani area, Southeastern Nigeria. Journal of Mining and Geology 15, 35-37.

Akpan, E.B., 1985. Ichnology of the Cenomanian - Turonian of the Calabar Flank, SE Nigeria. Geologie en Mijnbouw 64, 365-372.

Alves Martins, M.V., Hohenegger, J., Frontalini, F., Sequeira, C., Miranda, P., Rodrigues, M.A.C., Duleba, W., Laut, L., Rocha, F., 2019. Foraminifera check list and the main species distribution in the Aveiro Lagoon and Adjacent Continental Shelf (Portugal). Journal of Sedimentary Environments, 4 (1): 1-52. https://doi.org/10.12957/jse.2019.39308

Armstrong, H., Brasier, M., 2005. Microfossils (2nd ed.). Malden: Blackwell Publishing. Retrieved from http://www.getcited.org/pub/101980356
RESEARCH PAPER

Boboye, O.A., Okon, E.E., 2014. Sedimentological and geochemical characterization of the Cretaceous strata of Calabar Flank, southeastern Nigeria. Journal of African Earth Sciences, 99 (2) 427-441.

Braide, S., 1987. Clay mineral burial diagenesis: A case study from the Calabar Flank of the Niger Delta. Journal of African Earth Sciences 6 (2), 181-196.

Bronnimann, P., Whittaker, J.E., Zaninetti, L., 1992. Brackish water foraminifera from mangrove sediments of Southwestern Viti Levu, Fiji Island, Southwest Pacific. Revue de Paléobiologie 11, 13-65.

Cushman, J.A., 1938. Cretaceous species of Güembelina and related genera. Cushman Laboratory Foraminiferal Research, Sharon, Masc. U.S.A., vol. 14, pt. 1, pp. 11, 7.

Delavy, F.P., Figueiredo Jr., A.G., Martins, M.V.A., Rodrigues, R., Pereira, E., Brito, M.A.R.C. Fonseca, M.C.M. Laut, L.L.M., Bergamaschi, S., Miranda, P., Rodrigues, M.A.C., 2016. Highresolution acoustic mapping of gas charged sediments and living benthic foraminifera assemblages from the $\mathrm{NE}$ region of the Guanabara Bay (RJ, Brazil). Journal of Sedimentary Environments 1(3), 367-392. https://doi.org/10.12957/jse.2016.26281.

Dessauvagie, T.F.J., 1965. Preservation of Trocholina (Foraminiferida) in the Limestone of the Odukpani Formation in Eastern Nigeria. Journal of Mining and Geology and Metallurgy Society, 2(2), 57-64.

Edet, J.J., Nyong, E.E., 1994. Palynostratigraphy of Nkporo Shale Exposures (Late Campanian-Maastrichtian) on the Calabar Flank, SE Nigeria. Review of Paleobotany and Palynology, 80, (1-2), 131-147.

Edet, J.J., Nyong, E.E., 1993. Depositional environments, sea level history and palaeobiogeography of the late CampanianMaastrichtian on the Calabar Flank. Palaeogeography, Paleoclimatology, Palaeoecology,455, 16-32.

Ekpo, B.O., Essien, N., Fubara, E.P., Ibok, U.J., Ukpabio, E.J., Wehner, H., 2013. Petroleum geochemistry of Cretaceous outcrops from the Calabar Flank, southeastern Nigeria. Marine and Petroleum Geology, 48, 171-185.

Ekpo, B.O., Ibok, U.J., Essien, N., Wehner, H., 2012. Geochemistry and organic petrography of Cretaceous sediments of the Calabar Flank, southeastern, Nigeria. Marine and Petroleum Geology 35, 252-268

Fadiya, S.L., Adebambo, B.A., 2016. Campano-Maastrichtian Foraminiferal Stratigraphy and Paleoenvironment of Fika Shale, Bornu Basin, Northeastern Nigeria. Ife Journal of Science 18(3), 753-762.

Haq, B.U., Boersma, A., 1998. Introduction to marine micropaleontology. Singapore: Elsevier.

Horvath, K., Agnes, K., Gellai, N., 1989. Palaeobathymetric study of Palaeogene profiles upon foraminifera. M. All. Foldtani Intezet 2, 115-131.

Itam, A.E., Una, E.E., Udoh, M.U., Inyang, D.O., Emeka, C.N., Emeka, V.I., Bassey, E.I., 2019. Palynological evaluation of Cretaceous sediments of Ekenkpon Shale, Calabar Flank, Southeastern Nigeria. Journal of Scientific and Engineering Research, 6(7):156-164

Itam, A.E., Udofia, M.U., Inyang, D.O., 2017. Palynolostratigraphic study of PAMOL shale deposits, Calabar 
Flank, southeastern Nigeria. International Basic and Applied Basic Research Journal, 3(1), 1-10.

Itam, A. E., Inyang, D.O., Umana, S.U., Akpan, E.B., Udinmwen, E., 2016. Palynostratigraphy of Lemna road transect of Benin Formation, Calabar Flank, Nigeria. Asian Journal of Physical Science, Science domain International 1(1), 1-9. https://doi.org/10.9734/AJOPACS/2016/30942

Koutsoukos, E.A., Leary, P.M., Hart, M.B., 1990. Latest Cenomanian-Earliest Turonian low-oxygen tolerant benthonic foraminifer: a case study from the Sergipe Basin (N.E. Brazil) and the Western Anglo-Paris Basin (Southern England). Palaeo 77, 145-177.

Kumaran, K.P.N., Ramanathan, R.M., 1986. An upper Cretaceous assemblage from the Nkporo shale of the Calabar Flank. Journal of Paleontological Society of India 31, 9-15.

Laut, L.L.M., Martins, M.V.A., Frontalini, F., Belart, P., Santos, V.F., Lorini, M.L., Fortes, R.R., Silva, F.S., Vieira, S.S.S., Souza-Filho, P.W.M., 2016 a. Biotic (foraminifera and thecamoebians) and abiotic parameters as proxies for indication of the environmental heterogeneity in Caeté River Estuary, Amazon Coast, Brazil. Journal of Sedimentary Environments 1(1), 1-16. htps://doi.org/10.12957/jse.2016.21264

Laut, L.L.M., Clemente, I.M.M.M., Belart, P., Martins, M.V.A., Frontalini, F., Laut, V.M., Gomes, A., Boski, T., Lorini, M.L., Fortes, R.R., Rodrigues, M.A.C., 2016b. Multiproxies (benthic foraminifera, ostracods and biopolymers) approach applied to identify the environmental partitioning of the Guadiana River Estuary (Iberian Peninsula). Journal of Sedimentary Environments 1(2), 184-201. https://doi.org/10.12957/jse.2016.22534

Loeblich, A.R., Tappan, H., 1987. Foraminiferal Genera and their Classification. Van Nostrand Reinhold Company, New York. 970 pp. Available online at https://books.google.pt/books?id=n_BqCQAAQBAJ

Loeblich, A.R. Tappan, H., 1964. Treatise on Invertebrate Paleontology, Part C: Protista 2, Sarcodina, chiefly "Thecamoebians" and Foraminiferida. Geological Society of America and University of Kanzas Press, Lawrence.

Martins, M.V.A., Moreno, J.C., Miller, P.I., Miranda, P., Laut, L., Pinheiro, A.E.P., Yamashita, C., Terroso, D.L., Rocha, F., Bernardes, C., 2017. Biocenoses of benthic foraminifera of the Aveiro Continental Shelf (Portugal): influence of the upwelling events and other shelf processes. Journal of Sedimentary

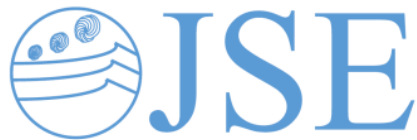

RESEARCH PAPER

Environments $2 \quad$ (1)

http://dx.doi.org/10.12957/jse.2017.28041

Martins, M.V.A., Soares-Gomes, A., Yamashita, C., Pinto, A.F.S., Frontalini, F., Sequeira, C., Laut, L.L.M., Belart, P., Zaaboub, N., Miranda, P., Sousa, S.H.M., Figueira, F., Pena, A.L., Terroso, D.L., Fernando Rocha, F., 2016. Similarity between the dead and living foraminiferal assemblages of the NE sector of Guanabara Bay (Brazil). Journal of Sedimentary Environments 1(4), 411-431. http://dx.doi.org/10.12957/jse.2016.26875

Martins, M.V.A., Frontalini, F., Rodrigues, M.A.C., Dias, J.A., Laut, L.L.M., Silva, F.S., Clemente, I.M.M.M., Reno, R., Moreno, J., Sousa, S., Zaaboub, N., El Bour, M., Rocha, F., 2014. Foraminiferal biotopes and their distribution control in Ria de Aveiro (Portugal): a multiproxy approach. Environmental Monitoring and Assessment 186 (12), 88758897. https://doi.org/10.1007/s10661-014-4052-7

Murray, J.W., 2006. Ecology and Applications of Benthic Foraminifera. Cambridge: Cambridge University Press.

Murray, J.W., 1991. Ecology and Paleoeocology of Benthic Foraminifera. New York: Longman.

Murray, J.W., 1973. Distribution and Ecology of Living Benthic Foraminiferids. London: Heinemann.

Murat, R.C., 1972. Stratigraphy and Paleogeography of the Cretaceous and Lower Tertiary in Southern Nigeria. In Dessuavagie, T.J. (Ed.), African Geology Ibadan: University Press, pp. 251-266.

Nagy, J., Alve, E., 1987. Temporal changes in foraminiferal faunas and impact of pollution in Sandebukta, Oslo Fjord. Marine Micropaleontology 12, 109-128.

Nyong, E.E., 1995. Cretaceous Sediments in the Calabar Flank. Geological Excursion Guidebook Calabar: 31 st Annual Conference of the Nigerian Mining and Geosciences Society, pp. 13-25.

Nyong, E.E., Ramanathan, R.M., 1985. A Record of oxygendeficient paleoenvironments in the Cretaceous of the Calabar Flank, SE Nigeria. Journal of African Earth Sciences 3(4), 455460. https://doi.org/10.1016/S0899-5362(85)80088-9 